\title{
Reimagining Gender Through Equality Law: What Legal Thoughtways Do Religion and Disability Offer?
}

\author{
Flora Renz ${ }^{1}$ (D) Davina Cooper ${ }^{2}$
}

Accepted: 26 October 2021 / Published online: 20 January 2022

(C) The Author(s) 2022

\begin{abstract}
British equality law protections for sex and gender reassignment have grown fraught as activists tussle over legal and social categories of gender, gender transitioning, and sex. This article considers the future of gender-related equality protections in relation to 'decertification' - an imagined reform that would detach sex and gender from legal personhood. One criticism of decertification is that de-formalising gender membership would undermine equality law protections. This article explores how gender-based equality law could operate in conditions of decertification, drawing on legal thoughtways developed for two other protected characteristics in equality law-religion and belief, and disability - to explore the legal responses and imaginaries that these two grounds make available. Religious equality law focuses on beliefs, communities, and practices, deemed to be stable, multivarious, and subject to deep personal commitment. Disability equality law focuses on embodied disadvantage, approached as social, relational, and fluctuating. While these two equality frameworks have considerable limitations, they offer legal thoughtways for gender oriented to both its hierarchies and its expression, including as disavowal.
\end{abstract}

Keywords Decertification · Disability $\cdot$ Equality law $\cdot$ Gender $\cdot$ Inequality $\cdot$ Religion

\section{Introduction}

Gender transitioning and the rejection of sex as fixed and binary have gained public ground in Britain in recent years. In the legal domain, attention has focused on procedures for gender's recertification (confirming people in their new sex and

Flora Renz

f.renz@kent.ac.uk

Davina Cooper

davina.cooper@kcl.ac.uk

1 University of Kent, Canterbury, UK

2 King's College London, London, UK 
gender) ${ }^{1}$ along with demands that sex and gender categories other than male and female also receive legal recognition. ${ }^{2}$ Currently, however, a new approach is gaining international attention. Rather than focusing on pluralising and simplifying recertification (such as through self-declaration), it proposes that state law withdraw from assigning, confirming, or requiring sex/gender status, including by removing sex from birth certificates. ${ }^{3}$ Arguments for decertification have been made on several grounds: the expansion of gender-neutral law, in liberal jurisdictions such as Britain, makes the formal gendering of people redundant; abolishing legal sex/gender status ameliorates difficulties faced by those whose personal sense of self aligns poorly with their formally assigned status; it allows people to live publicly without a formal gender label; counters the heteronormative assumption that gender matters (aside from as a cause of injustice); and decertification unsettles the naturalised alignment of gender with human subjects (see Cooper and Renz 2016; Cannoot and Decoster 2020; Cooper and Emerton 2020; Venditti 2020; Renz 2021).

Yet, the decertification of sex and gender is controversial, and opposition does not just come from conservative quarters. Proposals for de-formalisation have alarmed some feminists, especially those committed to sex-based rights. They fear eliminating the formal, binary-differentiated status of women and men will hinder women's struggles for justice, equality, and emancipation; undermine protection for women and girls by threatening single-sex services, spaces, and activities (see Burns 2016); and undermine the gathering of data necessary to evidence disparities between men and women's experiences, power, and resources (see generally Jeffreys 2014; Sullivan 2020; Stock 2021). They also argue that equality law protections will be fundamentally damaged if female and male are no longer formal, standardised categories (e.g. Murray and Hunter Blackburn 2019).

In our Economic and Social Research Council (ESRC)-funded research project, The Future of Legal Gender, we explore these concerns and offer responses to them. ${ }^{4}$ This article responds to the last claim: that sex and gender need to be formally assigned for equality law provisions to operate. We focus on this argument because it is one that we repeatedly encountered in our fieldwork from critics of decertification - that women's experiences of discrimination and disadvantage cannot be properly addressed, in equality law, if sex loses its status as part of legal personhood. To explore how equality law could operate in conditions where sex and gender are de-formalised, our focus is the Equality Act 2010. The Equality Act

\footnotetext{
1 Terminology around 'sex' and 'gender' is currently contested, and terms are used interchangeably and inconsistently, including in legislation. 'Gender', here, identifies the social production, manifestation, and expression of divisions relating to women/men, feminine/masculine, including in their rejection and pluralisation. 'Sex' identifies discourses that centre bodily difference, and 'sex/gender' indicates where both terms apply - either separately or together.

2 Many countries have introduced reforms in recent years to simplify processes for changing legal gender markers or adopting a non-binary marker (see e.g. Dunne and Mulder 2018).

3 More 'common' forms of decertification minimise gender's formal legal relevance through genderneutral legislation (Williams 2008) or gender's removal from ID documents (Wippler 2016), rather than abandoning it.

4 See The Future of Legal Gender: Exploring the Feminist Politics of Decertification, feminists@law 10(2) 2020; https://journals.kent.ac.uk/index.php/feministsatlaw/issue/view/45.
} 
foregrounds nine protected characteristics, including sex and gender reassignment. These two protected characteristics attract a range of rights, including formal protection from direct and indirect discrimination, a public sector equality duty, positive action, and the right to maintain some sex-specific provision. Our discussion focuses on these aspects in addressing decertification's consequences for equality law. While we respond to those who suggest decertification will make equality law protections impossible, we are also attentive to sceptics who suggest the impact of decertification on equality law would be modest given equality law's limited general efficacy, as well as antidiscrimination provisions' current recognition of lived status as women or men..$^{5}$ At the same time, current equality law tends to assume that people are (or are becoming) men or women-dimensions of selfhood presumed to be binary, ${ }^{6}$ enduring, and biologically straightforward. Decertification troubles this certainty. With legal status no longer assigned, questions arise about what sex and gender mean, how they are to be defined and determined, and the contours and scope of equality law protections.

This article foregrounds 'gender' as an (imagined) equality law category that combines the protected characteristics of sex and gender reassignment, and so incorporates sexed embodiment. It also incorporates other social dimensions of genderrelated inequality arising from how people identify, live, and are perceived. Considering the operation and implications of such a legal category is clearly speculative. What we address, in this article, is how it might work if it drew on legal 'thoughtways $^{7}$ developed for other areas of British equality law. The protected characteristics of race and sexual orientation within the Equality Act 2010 offer two areas where legal thoughtways have developed at a distance from assigned legal status (since people, in Britain, do not have a legally assigned or registered sexuality or race). However, our focus here is two other protected characteristics within the Act: 'religion and belief', and 'disability'. These two provide interesting sources for thinking about gender as a legal equality ground, post-decertification, particularly in their response to category definition, scope, and membership. Our argument in this article does not rest on suggesting that gender is a religion (or belief) or disability. What we are interested in are the legal thoughtways these two grounds offer for understanding and tackling disadvantage. In asking what this could mean for gender as a legal category, our discussion faces in two directions: towards those aspects of gender that equality protections target, and towards the re-envisaging of gender that they support and make intelligible.

Our discussion proceeds in two parts. First, we explore legal thoughtways developed for the protected characteristic of religion, focusing on equality law protections

\footnotetext{
5 This includes discrimination based on perceived or misrecognised 'sex' (Cowan et al. 2021). Other aspects of equality law allow distinctions to be drawn according to legal or biological sex. The extent and operation of these distinctions has been subject to intensive scrutiny and disagreement (see e.g. Sharpe 2020).

6 Although see Taylor v Jaguar Land Rover Ltd [2020] ET 1304471/2018, which recognised non-binary and gender fluidity within the protected characteristic of gender reassignment.

7 We use the concept of 'thoughtways' to capture a mix of legal principles, doctrine, judicial judgment, and scholarly analysis.
} 
for beliefs, practices, and community. We then turn to disability equality law, and explore how its features of embodiment, relationality, and fluctuation might apply to gender. Our aim is not to pit religion and disability against each other or to suggest one offers a better framework for addressing gender inequality. Each has different advantages and costs for a feminist critical analysis. We are interested in them as part of a shared repository. Equality law discussion can incline towards siloisation when it comes to different protected grounds. Our analysis aims to contribute to a more mobile, flexible approach. Translation and importation between equality grounds carries risks. But it also opens interesting questions about how different social relations and grounds of inequality are understood and legally addressed.

Before turning to our substantive discussion, we have three, final, introductory points. First, this article does not offer a detailed technical analysis of legal doctrine. We are interested, rather, in the broad principles, approaches, and understandings that British equality law works with. Second, we focus on equality law thinking rather than human rights law. In practice, these two have become entwined within the Equality Act case law. However, our interest is in gender as a structured relation of inequality rather than a personal right to be expressed. Third, our analysis recognises the importance of more far-reaching critiques of equality law. ${ }^{8}$ Several scholars have pinpointed the Equality Act's failure to address socio-economic inequality alongside other substantive injustices, such as the gender division of labour (e.g. see Fredman 2016; Malleson 2018). The law also suffers from inequality's compartmentalisation into discrete grounds-exacerbated in the failure to bring the limited provision for dual discrimination in the original Act into force. ${ }^{9}$ Thus, while we explore plausible revisions for remaking gender as a protected ground, we do not suggest that equality law frameworks such as the Equality Act 2010 provide adequate mechanisms for undoing systemic inequality or even for addressing disadvantages relating to minority religions and disability. The privileged status of Anglican Christianity as England's established church remains unaddressed in equality law; also unaddressed is the economic disadvantage that often accompanies disability, especially during periods of neoliberal welfare austerity (Ryan 2019).

\section{Drawing on Religion and Belief}

British religious equality law revolves around three claims. First, people should not experience discrimination, adverse effects, or hostile attention because of their religious affiliation, practices, or beliefs - and this injunction extends to non-religious 'philosophical' beliefs and to lack of belief as well (EA s 10(2)). Second, religions should experience some parity in their legal autonomy and treatment, although this is complicated by the established status of the Church of England and the uneven historically institutionalised settlements reached with other Christian and nonChristian denominations. Third, minority religions and beliefs, and their members,

\footnotetext{
${ }^{8}$ For an excellent exploration of the Equality Act limits, see Malleson (2018); for a recent evaluation, including proposals for new protected characteristics, see Bi (2021).

9 See s 14 Equality Act 2010 not currently in force.
} 
should receive some level of accommodation and support-currently addressed through indirect discrimination provisions and (limited) permissible affirmative action. These three claims underpin the Equality Act's response to religion, as the law parses a complex experience of the world into distinct (if not always welldefined) component parts: belief, manifestation/practice, and collective structure. In the discussion that follows, we take up these terms to consider their legal thoughtways for addressing gender inequality in conditions of decertification. The strength of religious equality law, for our purposes, is its attention to, and recognition of, diversity-including of beliefs based on a refusal to believe. At the same time, the emphasis on commitment and attachment, within a liberal multicultural paradigm, makes religious equality thoughtways less helpful for addressing gender as a structure of inequality.

\section{Gender as Belief}

Belief is a central feature of the Equality Act protections from religious discrimination. Commonly, in its wider usage, belief is used to denote claims that lack evidence. However, religious accounts give belief a special status when it comes to truth, worth, and what is 'real'. Some beliefs function as propositional claims that, while impossible (or not intended) to be confirmed through 'rational' epistemologies, operate as statements of truth nonetheless. ${ }^{10}$ Other beliefs depart from a concern with truth to emphasise commitment: 'I believe (in)' rather than 'I believe that' (Montemaggi 2017). Here, religious beliefs constitute connection, and a way of being in the world through belonging and faith (see also Ruel 2002), rather than a set of tenets (Kirsch 2004).

Equality law approaches beliefs as propositional claims about the world, the social relations that inhere within it, and the transcendent. Considerable academic and judicial attention has been paid to the breadth and limits of which beliefs count-in being properly religious or 'philosophical', sufficiently 'held', cognitively and morally acceptable, ${ }^{11}$ and appropriately manifested (e.g. Edge 2012). If gender, as an equality law ground, was approached in terms of beliefs giving rise to protections, what kind of beliefs might it entail? Contenders range from factual self-beliefs ('I am a man'), to other-facing beliefs ('they are non-binary'), to normative beliefs about society ('I believe in equality') and even speculative beliefs ('I believe gender will disappear'). Approaching gender as a source and site of beliefs that can be subject to equality law is not far-fetched. Sex-based rights feminists, who hold sex to be immutable and the central driver of gender inequality, have sought legal protection for their own descriptive and evaluative 'beliefs' about sex and gender transitioning.

\footnotetext{
10 On propositional beliefs' relationship to Christianity (see Ruel 2002; Kirsch 2004; Montemaggi 2017).

11 Non-religious beliefs are subject to a threshold test of whether they have attained the requisite level of "cogency, seriousness, cohesion, and importance", and are deemed "worthy of respect in a democratic society”, Grainger Plc \& Ors v Nicholson [2009] UKEAT 0219_09_0311 (para 10). For subsequent judicial analysis indicating how the threshold for protected beliefs has been drawn, see e.g. Thomas v Surrey and Borders Partnership NHS Foundation Trust 2304056/2018; and for explicit lowering of threshold see Forstater v CGD Europe and Others, UKEAT/0105/20/JOJ, para 79 (discussed below).
} 
In Forstater, the claimant challenged non-renewal of her consultancy contract, arguing her 'gender critical' views ${ }^{12}$ should be protected as a "philosophical belief". ${ }^{13}$ The Employment Tribunal commented,

The core of the Claimant's belief is that sex is biologically immutable. There are only two sexes, male and female. She considers this is a material reality. Men are adult males. Women are adult females. ... She will not accept in any circumstances that a trans woman is in reality a woman or that a trans man is a man. That is the belief that the Claimant holds. (para 77)

Alongside seeking juridical protection for their own beliefs about gender, some sexbased rights feminists argue that trans people's assertions about their gender identity also constitute beliefs (rather than statements of reality) - a contentious claim that equates some people's gender identity with states of mind or "form[s] of selfcreation" (Carlisle and Simon 2012, 233). Sex-based rights feminism distinguishes between the womanhood of cis-born women-depicted as socially and materially real since it is anchored, they claim, in biologically embodied sex-and that of trans women. ${ }^{14}$ From this perspective, decertification is problematic since it undoes the crucial distinction between a legal status that aligns with biological 'fact', and one based on social claims-making. In conditions of decertification, some may continue to assert the factual biological status of their sex or gender, but state law no longer formalises this status as a legal attribute. Thus, gender and sex risk becoming reduced to communal or private truth-claims.

Given different gender-based beliefs about the self, others, social life, and its values, norms, and sought-after futures, what might equality-as shaped and framed by equality law jurisprudence-here entail? At its narrowest, it suggests that people should not experience discrimination in employment, or in the provision of goods and services, because of their gender beliefs. But do all beliefs count for equality protections? In relation to religious and philosophical beliefs, a question posed for 'new' contenders is whether they are sufficiently meritorious or, instead, fall below the threshold, set out in Grainger, to merit protection. In relation to sex and genderbased beliefs, this issue arose in Forstater, where the Employment Tribunal held, "I consider that the Claimant's view, in its absolutist nature, is incompatible with human dignity and fundamental rights of others... if a person has transitioned from male to female and has a Gender Recognition Certificate that person is legally a woman. That is not something that the Claimant is entitled to ignore" (para 84). The Employment Appeal Tribunal, however, took a different approach, recognising gender-critical feminism as a belief that deserved equality protection-in part by establishing a much lower threshold for beliefs to cross. ${ }^{15}$

\footnotetext{
12 We use the phrase 'sex-based rights feminists' to reflect the main claim of contemporary gender-critical politics which situates reproductive capacity and biological sex at the heart of women's oppression.

13 Forstater v CGD Europe and Ors ET 2200909/2019.

14 For a broader articulation of sex-based feminism, see for instance Sullivan (2020), Stock (2021).

15 For an earlier case adopting a lower threshold re lack of belief in 'gender fluidity', see Higgs v Farmor's School: 1401264/2019, para 45.
} 
Whether this lower threshold becomes determinative in subsequent cases remains to be seen. ${ }^{16}$ However, what Forstater raises, particularly in the Employment Tribunal decision, is another issue: what direction do the beliefs face? In other words, beliefs about one's own gender may trump beliefs about others' gender, or even beliefs about gender more generally, when they conflict-as they do in cases where manifestation of a belief, including by withdrawal of a service, undermines or repudiates others' beliefs, as we explore below. In relation to religious beliefs, the invalidation of another's self-belief arises infrequently in equality law. But should people's beliefs about their own gender receive greater protection from discrimination than people's beliefs about others? For instance, is unfavourable treatment towards someone who self-identifies as a man (perhaps because they self-identify as a man) more problematic than discrimination against a person who identifies someone else as a man (as in Forstater)?

At first glance, the rationale for self-beliefs' trumping status seems obviouswhether anchored in, and justified by, subjects' lack of control over what they think they are (rendering a consequential penalty unjustifiable as a result) or by the value placed on self-cultivation and identification as part of self-development. ${ }^{17}$ From this second perspective, making people subject to others' determinations about their gender is oppressive and infantalising, undermining personal dignity and autonomy. Yet, there are also under-attended-to problems in drawing a clear normative line between self-focused and other-focused (or wider-focused) beliefs. Privileging people's selfbeliefs may appear reasonable, but it has been criticised for making demands on others (sometimes framed as 'compelled speech') (discussed in Cooper 2019a). In religious equality law, remedies for discrimination can be denied where the unfavourable treatment results from the claimant's attempts to convert or put unwanted religious pressure on others (Vickers 2015). ${ }^{18}$ Some feminists have sought to make an analogous argument, claiming they are forced to communicate a message regarding beliefs they do not hold when asked to respect other people's self-identified gender (see Forstater, Employment Tribunal, para 91).

Compelled speech can seem a form of coerced conversion. Yet, one difficulty with the objection to compelled speech is that it typically targets controversial beliefs (or reframes specific beliefs and actions as controversial). Conventional claims are less frequently identified as beliefs and so as necessitating reining-in to avoid over-sharing with, or imposing on, reluctant others. Instead, they operate as public norms - the cultural expectation, for instance, that people reciprocate happy Christmas or Easter wishes. Sex-based rights feminists, for instance, do not treat claims about their own gender (or sex) as imposing beliefs on others since they consider their sex and gender to be real. We therefore question reliance on arguments

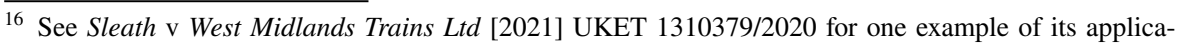
tion.

${ }^{17}$ The degree of choice and control held by people over their beliefs is disputed, see Fredman (2011, 131-134).

${ }^{18}$ See for instance Chondol v Liverpool City Council [2009] UKEAT 0298_08_1102; Wasteney v East London NHS Foundation Trust [2015] ET 3200658/2014.
} 
about compelled speech to insulate people from having to respect others' self-facing beliefs. At the same time, we also question the individualism that underlies many claims to self-categorisation. Beliefs about one's own gender are shaped by beliefs about gender as a category, about others' gender, and by others' beliefs about oneself. These latter beliefs may be supportive-holding up and indeed contributing to self-focused beliefs. But people's beliefs about their own gender can also be constituted defiantly-resisting or refusing beliefs about oneself that others hold. The important point, here, is that beliefs are political-directly or indirectly they are claims about the social world and about others (see also Cooper 2019a, ch 4).

Gender can develop as an equality ground that is attentive to beliefs without too much difficulty, drawing on and translating legal thoughtways developed and applied to religious and philosophical beliefs. The difficulty does not lie in extending beliefs to gender-related beliefs-recognising the parallels when it comes to (un)acceptable beliefs as well. Rather, the difficulty lies in determining how equality law should respond to beliefs more generally. In the case of gender, beliefs cover very different terrain-from a belief in men as properly masterful to a belief that sex is immutable, that gender should be abolished, or that oneself or another person is female, male, genderqueer, or something else. Given this diversity, beliefs about gender are not good targets for equality actions, for instance in relation to the public sector equality duty (PSED) or positive discrimination. In other words, state and law should not treat different gender beliefs as equally valid, nor should they adopt a form of disestablishment that denies all gender-related beliefs public normative status (see also Cruz 2002). Some beliefs should be advanced by state bodies; others should not be. However, to the extent that beliefs form an important target for equality law, this derives from their 'possession' in conditions where value is placed on protecting people from the discrimination that might otherwise ensue. At the same time, beliefs are rarely just held; they also get expressed through practice. ${ }^{19}$ Therefore, what people do with their beliefs matters. Not all manifested expressions of gender beliefs-whether as speech acts or other activities_-should be legally protected in equality law.

\section{Gender as Practice}

Practice forms a centrepiece of religious equality law since it foregrounds individuals' ability to manifest their religion. Here, remedies for direct and indirect discrimination come into play, along with demands for accommodation, so that a workplace or sector structured around dominant practices adjusts to enable minority practices also (Alidadi 2012; Edge and Vickers 2015). An extensive body of case law addresses (minority) religious expression at work: from wearing garments and religious symbols to observing specific prayer times and holy days, scriptural advocacy, and dietary laws. Since the category of philosophical belief also carries legal

\footnotetext{
19 Practices' capacity to give rise to beliefs is less frequently addressed; the belief-led approach has been criticised for privileging a Christian religious paradigm; see also Danchin and Blond (2014).
} 
protection, litigated-over practices are not just religious but include, for instance, veganism or vegetarianism as well. ${ }^{20}$

Not all practical expressions of recognised religious and philosophical beliefs, however, receive equality law protections (e.g. see Hambler 2020). A series of legal distinctions come into play to determine what counts as an acceptable manifestation. These include whether practices manifest beliefs or are motivated by them; whether forms of manifestation are collectively acknowledged as necessary or constitute an idiosyncratic individual response; and whether the practice relates to a religion's core or to its periphery. These legal distinctions have been applied unevenly and subjected to critical discussion (e.g. Edge and Vickers 2015). One controversial context concerns religious-based acts of refusal: conservative Christians, for instance, who refuse to marry or counsel people in same-sex relationships or recognise them as suitable to adopt children (Stychin 2009; Vickers 2010; Cooper 2019a). Another is the refusal to recognise trans women as women. Refusal, here, forms a doublesided practice for equality law. Those who are denied a service may claim discrimination but so too may the provider or employee who faces penalties for their beliefbased refusal to comply.

These complexities highlight the difficult place of practices in thinking about equality law. In relation to gender, equality might entail an equal right to manifest one's gender (including one's gender beliefs) or, alternatively, an entitlement to an equality of persons that gendered practices undermine. Thoughtways offered by religious equality law foreground practices undertaken to express cultural-religious traditions and beliefs. Applied to gender, accommodation could mean allowing women extra grooming time at work in recognition of the greater demands placed upon them. It could also give rise to men's claims that nude female pin-ups at work be accommodated as an integral part of some heteronormative masculine cultures.

Equality for different gender practices follows the logic of multicultural diversity. As such, it also falls subject to critiques of such logic-specifically, that it obscures existing inequalities and fails to recognise how practices and subjects are relationally and asymmetrically constituted. Accommodating women and men's gender practices, whether it is asymmetrical grooming norms, extra care responsibilities, or sexist forms of masculine expression, treat difference as benign rather than something that, itself, undermines equality. Drawing on thoughtways from religious equality law also foregrounds gender practices (that is, practices directed and required by gender membership and beliefs) rather than a much broader array of gendered practices (that have unequal gendered effects). Yet, equality requires this wider set of practices to be addressed as well. To a limited extent, sex equality law already does this, through indirect discrimination provisions. ${ }^{21}$ Whether such provisions will be less effective in conditions of decertification remains unclear. What it does suggest, however, is a potential value in extending equality law grounds: for

\footnotetext{
${ }^{20}$ See e.g., Conisbee v Crossley Farms Ltd \& Ors [2019] ET 3335357/2018; Casamitjana v The League Against Cruel Sports [2020] ET 3331129/2018.

${ }^{21}$ E.g., see Burden v Chief Constable of Hampshire Constabulary (ET 3100659/2014).
} 
instance, to address the disadvantages carers face as carers, without requiring that care be legally aligned with sex or gender-based categories.

One context, however, where religious equality law may offer useful thoughtways is in supporting and protecting new forms of expression. This support may seem to reify difference. Yet, while equality law embraces new religions and beliefs, it also embraces lack of religion and belief. Adopting a similar framework for gender protects practices that manifest new gender identities and beliefs, for instance, in relation to dress and appearance, categories on official forms, ${ }^{22}$ and practices such as asking and displaying one's pronouns. But it can also protect practices that express a lack of gender identity or self-belief. Protection for people with agender identities ${ }^{23}$ for instance - that is, people who refuse to locate themselves within a gender framework-poses a significant shift away from the current binary sex-based framework, which treats its two categories as exhaustive. Expansion of gender in this way, however, is not insulated from feminist critique. Approaching agender as an identity can seem to individualise and depoliticise a wider emancipatory politics-protecting practices because they express an individual or group's identity and beliefs rather than as a means of abolishing gender. Legal recognition for multiple gender categories, that include agender, risks taming more challenging feminist agendas, locking in rather than undoing a governmental gender-recognition system (see also Katyal 2017; Clarke 2019). Agender also suggests people can choose a non-gender identity in conditions where gender continues to saturate social life. There are similarities here with atheism, which religious equality law protects. Arguably, at some level, atheist living is impossible in societies where religion remains pervasive and institutionalised. In Britain, life continues to be structured and shaped by religion, as it influences and permeates law, culture, politics, festivities, calendars, etc., even in contexts where individuals disavowed it. Yet, equality protections for atheists, who live as if religion did not define or saturate their lives, remain important, including for their capacity to contribute to religion's diminishment within societal institutions more generally.

Accommodating agender practices, and legally countering the adverse effects faced by those who seek to live outside of gender norms, provides institutional bolstering and space for new ways of being. Currently, these include androgynous dress and unconventional forms of personal grooming and expression, neutral pronouns, degendered celebrations such as b-mitzvahs, and non-gendered child-rearing. We might also include combinations of work (paid and unpaid) and responsibilities that, in their mix, fail to conform to gender-differentiated norms. While some agender practices seem minor, and while many are already underway, recognising them in equality law, in conditions of decertification, could enhance a broader feminist project that seeks to undo the asymmetries, divisions, and alignments that gender

\footnotetext{
22 For instance, the Gender Representation on Public Boards (Scotland) Act 2018, statutory guidance, suggests that "continuously living as a woman" can be evidenced by "always using female pronouns or a female name on official documents" (Scottish Government 2020).

23 Uses of the term 'agender' vary. In this article, we use it to signal gender's disavowal rather than its non-binary take-up.
} 
regimes establish. Equality law recognition removes some precarity and strain from living as agender. ${ }^{24}$ Remedial protections, PSED, and affirmative action measures also make agender more plausible as taken-for-granted distinctions between women and men are challenged - not simply by claims and arguments, but by ways of living which refuse gender as a norm-generating structure.

\section{Gender as Community}

Finally, we turn to equality law's approach to religious communities and groups. These fold into British equality law in three quite different ways. First, public sector equality duties and the promotion of 'good relations' target communities and groups through their 'protected characteristics' (see also Vickers 2011). Second, religious communities connect and encompass the religious individuals that form equality law's primary subjects. Organised communities shape the practices and beliefs which individuals hold (see Edge 2012); connect people to each other (and to the transcendent or divine); and may, more injuriously, provide targets (directly or indirectly) for ethno-religious discrimination, unequal treatment, harassment, and violence. Third, organised religious communities undertake discrimination. This may be permitted positive action to counteract subordination. The Supreme Court declared in $R$ ( $Z$ and anor), a case on housing allocations by an orthodox Jewish charity, that action in favour of community members could be undertaken "to meet the particular needs and alleviate the particular disadvantages experienced by members of the ...community" ${ }^{25}$ Discrimination can also take a negative form-against community members (or entrants) with stigmatised protected characteristics, gay, lesbian or trans, for instance, against heterodox members who disagree with how the religion is practised, or against those deemed not to meet the religion's membership criteria.

What thoughtways does religious equality law's approach to organised community offer for thinking about gender equality in conditions of decertification? We should emphasise here that we are not concerned with how gender is treated within religious communities, but with communities of gender themselves. For the most part, in Britain, women and men share community spaces. However, gender-specific religious, occupational, and cultural communities also exist. Some articulate conservative gender norms, others are more radical or non-conforming: from the 1980s flourishing of lesbian and separatist spaces, peace camps, and women's lands (see Roseneil 2000; Browne 2009) to contemporary genderqueer and non-binary communities of practice and co-presence, including online (see e.g. Yeadon-Lee 2016; Stone et al. 2020). In recent years, conflict over admittance to women-only spaces has intensified. Focused on the use, participation rights, and compelled mixing of trans and non-trans women, conflict has involved lesbian organisations, changing rooms, toilets, refuges, and prisons (Murray and Hunter Blackburn 2019; Cowan et al. 2020; Sharpe 2020). These conflicts involve disputes about what gender

\footnotetext{
${ }^{24}$ See for instance a recent US decision to recognise a person as 'genderless' O'Hara (2017).

${ }^{25} R$ (Z and anor) v Hackney Borough Council (and anor) [2020] UKSC 40, para 79.
} 
categories mean, on who gets to decide, and who gets to determine individuals' placement within or outside of the category. Critics of decertification suggest such conflicts will intensify in conditions of decertification where legal sex and gender status no longer exists. In the discussion that follows, we draw on equality law's thoughtways for religious community to address three issues: how might gender, in general, and the sub-categories it gives rise to, be defined; what developmental role can equality law play; and does the focus on community or group contribute to gender's reification?

In conditions of decertification, how might gender-based groupings be identified for equality law purposes? The approach currently adopted for 'sex' defines it through its two sub-categories (female and male). Post-decertification, sex might remain one descriptor of what falls within the category of gender. But to the extent the focus shifts away from sex, how is this category, with its distinct features and qualities, to be determined? If legislatively encoded as an equality ground, should gender be described through its key dimensions (as the Equality Act does for race), ${ }^{26}$ operate through an open or closed list of members, describe certain recognised consequences (as with disability), or be treated in some other way? Religion here provides one framework. The Equality Act s10(1) states "Religion means any religion and a reference to religion includes a reference to a lack of religion". Thus, case law rather than statute establishes what religion means (and which religions count), in temporally evolving ways. Applied to gender, this could allow different genders to emerge and be recognised, over time (including non-binary, agender, and genderqueer), including for purposes of direct and indirect discrimination, affirmative action, and the PSED. But definitional questions remain: What does gender itself refer to? What is involved in being a gender grouping (rather than some other kind of grouping)?

Case law on religious equality has had to address the question of definition (see Jivraj 2013), deliberating on the place of god and the spiritual for "a belief system which goes beyond that which can be perceived by the senses or ascertained by the application of science". ${ }^{27}$ What would an analogous approach to gender look like? Gender's relationship to sex may appear loosely analogous to religion's relationship to the divine-a conventionally perceived requirement or anchor that is no longer treated as obligatory. But if gender lacks an essence, should it become an equality ground based on a loose constellation of historically related qualities: different kinds of sexed embodiment, lived and perceived gender identifications and practices, the take-up (and mixing) of masculinity, femininity and the androgynous? We return to these qualities in the section on disability that follows.

The second question posed by the thoughtways that religious equality law has developed concerns its developmental aspect. This emerged in the Supreme Court decision of $R$. ( $Z$ and anor), where the court treated the housing allocation policy of an orthodox Jewish organisation as "legitimate "positive action" rather than

\footnotetext{
26 Equality Act 2010, s 9 indicates that race includes colour, nationality, and ethnic or national origin.

27 See Hodkin \& Anor, $R$ (on the application of) v Registrar-General of Births, Deaths and Marriages [2013] UKSC 77, para 57.
} 
"unlawful 'positive discrimination' given members" needs, under Equality Act s $158 .^{28}$ It also, importantly, recognised the orthodox Jewish community as a legitimate collective entity whose sustainment and flourishing required support, for instance, by enabling community members to live in close proximity (para 35(4)). A developmental dimension also emerges in the PSED of the Equality Act (see Manfredi et al. 2018). Section 149(1) requires public bodies, in the exercise of their functions, to have due regard to eliminating discrimination, harassment and victimisation; advance equality of opportunity between people who do and do not share a protected social identity; and foster good relations. Public bodies already exercise equality responsibilities towards differently sexed and gendered constituencies (Cooper 2020), although in recent years, this has tended to involve organisational and discursive distinction-drawing between initiatives relating to sex (usually understood as ‘women'-often, although not always, imagined as cis-women), and initiatives relating to gender (increasingly interpreted as transgender). In conditions of decertification, gender as a developmental equality ground could combine different dimensions of how gender is lived, embodied, perceived, and treated; but approaching gender in this way also poses a feminist problem. Does it assume gender category membership constitutes a positive relationship-for both individual and society? This assumption sits uneasily alongside feminist arguments that gender is an undesirable relation of inequality that should not be legitimated (or mystified) through reformulation as a benign identity and positive attachment.

The notion that treating sex and gender as identifications means treating them as benign has recently been complicated by Katharine Jenkins (2016). Drawing on Sally Haslanger's work, Jenkins explores identity through the idiom of a map that orients subjects rather than a desired property of the self. ${ }^{29}$ She writes, "In the context of current dominant ideology, having a female gender identity means having an internal 'map' that is formed to guide someone who is subordinated on the basis of having actual or imagined bodily features that are presumed to be evidence of a female's role in biological reproduction through the social or material realities characteristic of a person who is so subordinated" (Jenkins 2016, 410). This resonates with accounts of religion that trouble the assumption that membership is necessarily a positively chosen attachment, given the force of socialisation within religious traditions, and people's often ambivalent relationships to the traditions and communities they self-identify as belonging to. ${ }^{30}$ But even if identification doesn't entail positive attachment, does legal recognition for developmental purposes still give rise to reification? Analogised to religion, gender emerges as a set of discrete constellations_-women, men, non-binary, etc.—combining beliefs, practices, and affiliations. This seems problematic to the extent it differentiates people according to gendered packages of attributes. At the same time, recognition is helpful for new groupings

\footnotetext{
${ }^{28} R$ (Z and anor) v Hackney London Borough Council \& Anor [2020] UKSC 40, para 46.

29 This may also helpfully reorient a religious equality framework to better recognise those religions that also exist as ethnic heritages in contrast to the belief/commitment orientation of a Christian-driven religious paradigm.

30 Thanks to Lucy Vickers for reminding us of this point.
} 
and communities as it posits and protects their existence. Beyond individual protection from discriminatory treatment, recognising, for instance, agender in community or group terms, including through the PSED, supports the development of its degendered collective structures, and the meanings, norms, cultures, and politics they give rise to.

In the discussion that follows, we explore the framework that legal disability offers for reimagining gender as an equality law category. But first we briefly summarise our discussion so far. Drawing on legal thoughtways developed to advance religious equality protections takes gender equality away from the dualist framework of sex. Instead, gender becomes read through its beliefs, practices, and community groupings. This resonates with new emerging understandings of gender as plural, expressive, plastic, changing, and self-authorising. Some feminists have criticised these developments as individualistic and depoliticising-recuperating gender rather than supporting its abandonment as an organising frame for social life (discussed in Cooper 2019b). However, following the approach taken to religion in equality law, the recognition which equality law offers gender-based communities includes communities defined through gender's disavowal. Equality law protects individuals from discrimination; but it also supports and, through the PSED, obliges public bodies to ascertain group needs and impediments. This has the potential to support new practice-based groupings that refuse the dualistic gendered assumptions of mainstream life even as it also risks further reifying gender as a set of distinct, socially patterned differences.

Religious equality thoughtways also have other limitations when drawn on for gender in conditions of decertification. While the strength of religious equality law, in Britain, lies in its attentiveness to diverse communities organised around different beliefs and practices, its thoughtways remain less attentive to the institutional inequalities historically bequeathed, such as the practices and consequences of Anglican Christianity. It is also less attentive to differential experiences of embodiment. Bodies figure in religious equality law largely as bearers of religious symbols (crosses, headscarves, etc.) or as sites of religious gestures and rituals, such as prayer. They are less attended to as sites of difficulty or pain-contexts where equality law might otherwise provide compensatory mechanisms. Religious equality law also pays limited attention to how social experience, status, and identity shift-whether by context or across the lifespan. Conversion is, of course, allowed for. But equality law's focus is commitment and attachment, the detrimental results that attend belonging, or from not being treated as belonging, rather than from experiences of identity and membership flux. Thus, in the discussion below, we consider what disability equality frameworks might offer for thinking about gender in conditions of decertification. Our analysis focuses on the legal devices and rationalities that disability law brings to tackling relations of subordination and marginality vis-à-vis a hegemonic norm; the place of embodiment in experiences of inequality and in the legal remedies offered; and the fluctuating and relational character of membership. 


\section{Thinking Gender Through Disability}

Disability theory has long engaged with feminist theory and the role of gender (see e.g. Lloyd 1992; Kafer 2013; Wendell 2013), an engagement that has often taken the shape of a challenge-whether to feminist theory for its failure to account for disability, or to disability theory for failing to build on feminist scholarship. Here, we explore attributes and qualities that equality law associates with disability to consider the legal thoughtways this presents for tackling gender as a protected equality law ground in conditions where gender becomes untethered from formal legal personhood. In the previous discussion, we focused on different ways of viewing gender, namely as beliefs, practices, and community. Here, we focus on gender as complexly and heterogeneously embodied, relational, and as varying in intensity and relevance across different times and settings.

Considering gender through the lens of disability can seem problematic to the extent it depicts gender, and particularly femininity, as a negative quality or as a deficit. Feminists have criticised the historical legal analogy between disability and pregnancy for this very reason. However, notions of lack run counter to much contemporary disability scholarship, which conceptualises (dis)ability primarily as a point of difference that may be associated with undeserved social stigma, akin to sexuality, rather than as an inherently negative characteristic (McRuer 2006; Kafer 2013). Yet, how to conceptualise disability in equality law thoughtways remains subject to some dispute. Prevailing approaches mainly take one of three forms: medical, social, and, more recently, critical. The medical model suggests that people are disabled by their impairments or differences. These impairments or differences should be 'fixed' or altered to minimise their effects, even when the impairment does not cause pain or illness. As such, disability becomes an individual rather than structural problem (Flacks 2012; Martin 2012). The social model of disability treats disability as the outcome of a negative interaction between a mental/physical impairment and physical or structural barriers, which prevents someone from accessing spaces or participating fully in social life (e.g. Barnes 2007; Woods 2017). Finally, critical accounts of disability highlight both the effects of societal barriers to inclusion and the disabling effects of impairments themselves, particularly those that cause pain and fatigue (McRuer 2006; Kafer 2013). They also emphasise the need to acknowledge and embrace minority practices within disability culture that are routinely hidden or erased by models that view disability primarily as a problem to be 'fixed', whether through medicine or equality law.

The Equality Act draws on these different approaches; however, it aligns most closely with a social or human rights model of disability, focusing on adjustments that others should make in response to disadvantage experienced by a disabled person (Degener 2016). Importantly, disability in the Equality Act functions asymmetrically, rather than symmetrically as it does for religion and sex (Lawson 2011). Current equality law justifies this approach through the embodied effects of impairment. Disability in the Equality Act is defined as "a physical or mental impairment" 
which has "a substantial and long-term adverse effect". ${ }^{31}$ While this broad definition encompasses a wide array of conditions, some evidence suggests that it works better, in practice, for physical impairments than conditions with less well-defined bodily markers, such as neurodiversity (Lawson 2011; Harwood 2016). Disability case law, particularly in first instance tribunals, typically focuses on whether the claimant factually has a disability for the purpose of the Equality $\mathrm{Act}^{32}$ and, if so, whether this was given due consideration by the other party. Our analysis, in contrast, foregrounds the broader legal thoughtways disability equality law offers to assess their value for remedying gender inequality, and how gender might be reimagined in the process.

\section{The Place of Embodiment}

Disability thinking and equality law do not ignore embodied experiences. However, they also do not centre impairment as the primary source of oppression or disadvantage. In the social model of disability (e.g. Oliver 2013), partially adopted by the Equality Act, barriers to accessing spaces or outright discrimination arise from social norms that privilege specific bodily capacities, e.g. the ability to climb stairs, which unequally shape people's choices and life chances (Fredman 2016, 731). The Equality Act defines disability not just through the existence of an impairment, but where this impairment also has "substantial and long-term adverse effect on P's [a person's] ability to carry out normal day-to-day activities". ${ }^{33}$ This definition distinguishes disabilities that are recognised in equality law from impairments that, particularly if responsive to medical intervention, have little impact on daily life.

If sex and gender reassignment were combined into a new equality ground of 'gender', approaching this ground through legal thoughtways used for disability protections keeps embodiment central (as sex-based rights feminists advocate). However, while disability thoughtways recognise the importance of bodily configurations and the ways these can lead to inequality, embodiment is not tied to a fixed or binary status. In conditions of decertification, equality law could recognise the specific effects of menopause, for instance, on someone's daily life and provide appropriate legal protections. Critics' concerns that decertification would lead to an erasure of bodily difference seem misplaced. Disability-focused equality law takes embodiment seriously in a way that is complicated, multiplex, and open-ended. The Equality Act acknowledges that different impairments can lead to different effects and so should not be treated as identical or subject to identical adjustments. Applied to gender, this would allow for recognition of a diverse range of bodies rather than assuming that inequality and discrimination derive from a division between two clearly differentiated bodily forms. These bodily forms do not derive from biology alone; they are also shaped by environmental, technological, pharmacological, and medical

\footnotetext{
31 s 6(1) Equality Act 2010.

32 See Donnachie v Telent Technology Services Ltd: 1300005/2020 and Rooney v Leicester City Council: 2600242/2019 and 2600243/2019: two recent tribunal decisions on whether menopause is a disability.

33 Equality Act 2010, s 6(1)(b).
} 
interventions, including through the use of hormones and medication that triggers hormonal changes (such as contraceptive pills, anabolic steroids, or Viagra). Such an approach seems able to accommodate bodies that diverge from binary gendered and sexed norms, such as trans or intersex bodies for instance.

\section{Gender and Relationality}

A second dominant thoughtway within equality law approaches disability as relational (Kafer 2013). Relationality is an important aspect of social inequality and the subject positions it gives rise to. It contests the idea that women, men, disabled, and able-bodied people are discrete, free-standing, stable figures. Relationality, however, is often used as a composite term in ways that obscure its different dimensions. In this discussion, we draw attention to three intersecting aspects: that subject positions are socio-materially constituted-produced in interaction with the material world of spaces and people; that subjecthood is defined and given meaning in asymmetric relational ways; and that subject-positions, and well-being, depend on support from others.

Taking relationality in the first sense, what constitutes a disability depends on interactions with other people, agencies, institutions, places, and objects. The embodied experiences discussed earlier are continuously shaped by, and generated through, interaction with others. Equality law is attentive to how material conditions interact with specific impairments to produce inequalities of access and participation. Beyond the concrete effects of an impairment, disability comes into being through interactions, particularly between human and non-human-in the form of objects and architecture (Latour and Serres 1995, 161). This means that reduced capacity can often be remedied by modifying the material conditions that give rise to it. The availability of step-free public transport, the provision of live-captioning or British Sign Language interpretation, the design of easily readable formats for public information, sit at the intersection between materiality and capacity, and determine who has less (or more) capacity to act, where the default option is determined by the dominant mode of construction of the material world. Consequently, the duty to make reasonable adjustments, on grounds of disability, to practices, spaces, and objects, to remedy and prevent inequality lies at the heart of the Equality Act's engagement with disability.

A second way relationality figures is in how disability, or what it means to be disabled, gets defined and measured against a hypothetical non-disabled person. Disability only comes into existence in interaction with socio-cultural norms that define what dis/ability looks like and in relation to non-disabled persons or people with a different disability — a 'mental impairment', for instance, versus a physical one. Equality law intervenes in these relationships where difference leads to inequality for a specific population or group. More generally, rather than purely endorsing or minimising these different aspects of relationality for disabled people, equality law is attentive to them. This includes required adjustments that enhance disabled people's autonomy in everyday activities, such as producing important government documents in formats that are easily understandable or that can be straightforwardly read by screen readers. At the same time, equality law approaches disability 
as relational in a third sense, in terms of required relations of support. Impairment suggests that people cannot manage within existing material conditions-with their tacit expectation of certain kinds of physical and mental capacity-without support or assistance from others, including through financial resources, personal assistants, interpreters, and care workers. ${ }^{34}$ Disability, in this sense, counterposes the liberal ideal of the autonomous individual proceeding through the world without help from others (see also Nedelsky 1990).

These three forms of relationality converge in the PSED on disability. This duty addresses, first, the material production of disability and the importance of attending to the physical landscape. For instance, the PSED is generally interpreted as requiring public bodies to carry out equality impact assessments to ensure newly built or renovated facilities are accessible to disabled people who have a variety of impairments. ${ }^{35}$ Second, the asymmetrical difference that underpins disability's definition is addressed through actions to minimise this difference and reduce stereotyping. For instance, employers are encouraged to interview all qualified disabled applicants through the Disability Confident scheme despite positive discrimination measures being otherwise very limited in British equality law (Department for Work and Pensions 2016). Third, the PSED includes a duty to provide disabled people with additional resources and support. ${ }^{36}$ The PSED also offers a pathway to greater social justice by providing additional review mechanisms to ensure public bodies meet disability equality duties in their delivery of services and spending (Carr 2014; McColgan 2015).

What can we take from equality measures that address the relational character of disability in thinking about a new PSED for gender in conditions of decertification? We do not want to overstate the value of these legal thoughtways for gender. While disability-based equality law is more responsive to the asymmetrical character of disadvantage than is religion within equality law, it still offers a paradigm that leaves prevailing norms and other social structures relatively untouched. The main remedy offered by the Equality Act, and reviewed through the PSED, is the duty to make 'reasonable adjustments' (Lawson 2008). Despite going beyond the legal obligation to refrain from indirect discrimination, this positive duty is limited to redressing individual instances of inaccessibility. It does not require employers, for instance, to take proactive steps to ensure a workplace is accessible to people with all types of different (dis)abilities. ${ }^{37}$ It may also prove more individualised than the legal thoughtways that religion makes available, since the focus on religions (and not just individual members) allows the courts to address the needs of community structures, as in $R$ ( $Z$ and anor). Our discussion therefore focuses in general terms

\footnotetext{
34 See $R(T P, A R \& S X C)$ v Secretary of State for Work and Pensions [2020] EWCA Civ 37 on benefits changes.

35 . (Buckley) v Bath and North East Somerset Council [2018] EWHC 1551 (Admin).

${ }^{36} R$ (Chavda) v Harrow LBC [2007] EWHC 3064 (Admin); $R$ (Coleman) v Barnet LBC [2012] All ER

(D) 256 (Dec); $R$ (Bracking \& Ors) v SSWP [2013] EWHC 897 (Admin).

37 s 20-22 Equality Act 2010.
} 
on the relational dimensions of gender, prompted by legal thoughtways relating to the PSED for disability.

The socio-material production of gender operates at different levels. At one level, it concerns how the built landscape is skewed towards gendered norms that privilege certain heights, strengths, and functions (e.g. see Criado-Perez 2019). This treats gendered subjects as already in existence, confronting an environment that may help or hinder them. At another level, gender itself is produced through social and material relationships, including divisions of labour and care responsibilities, media representations, and sexual violence. Can legal thoughtways generated by the PSED for disability be drawn on to minimise these gender-producing processes? One contemporary example might be municipal-retail policies and initiatives to tackle how products, such as clothes, grooming aids, and toys, are priced and marketed to appeal to specific gender-based classes of consumers. These customers (and their children), in turn, are hailed and socialised, for instance as boys and girls, through their interaction with these products (Coyle and Liben 2020). Regulatory moves to counter the production of asymmetrical gendered subjects are already taking place in other fields, such as the recent ban on gender stereotypes in advertising (ASA 2019). Drawing on the PSED for disability suggests these measures might be extended to address other ways in which gender norms are reinforced.

Policies and practices to undo gender's social and material production also speak to a second understanding of relationality - namely, how gender is defined and understood through oppositions and differences. This has been conventionally understood to mean that women are everything that men are not, and vice versa-a set of oppositions that are hierarchically ordered and naturalised through heterosexual norms of complementarity. Other research has complicated this binary by suggesting that genders, like religions, are also defined by differences between different versions of the 'same', for instance between different forms of masculinity as Connell and others have explored (e.g. Connell 1995; Connell and Messerschmidt 2005). Measures to undermine the social production of gender also counter the notion of gender as complementary and contrasting characteristics - as with measures to remove gender-targeted toy retailing. A different way a PSED might work is in responding to gendered forms of plurality. The notion of gender categories being defined against each other is less stark when there are multiple gender categories rather than two. Thus, using the PSED to recognise non-binary and other gender categories unsettles a contrastive, hierarchical, binary framework (although one risk is that it establishes another intersecting binary, as with the distinction, for instance, between cis and trans).

Our third relational dimension concerns interpersonal support. In the case of gender, assistance, support, and mutuality can mean different things. It can mean enabling people to persist in their gender or well-being through others' exploitationan argument that feminists have made about women's domestic labour holding up men's patriarchal masculinity. The notion of 'supporting gender' has also made some feminists uneasy with its overtones of gender affirmation (e.g. Segal 2015). However, we want to approach the PSED here as meaning something differentthat people's equal entitlement to well-being requires social relationships, attention, and care. Feminists have long argued that these should not be women's specific 
responsibility, made disproportionately available to men, or delivered to women in a patronising form. But, with these caveats, care, interdependence, and sociality might be placed at the heart of equality thoughtways. This often translates into child care and elder care so that women, as gendered subjects, are not held back-a formulation that risks reverting to a framework of stable gendered subjects advantaged or disadvantaged by an environment that they confront (rather than also being formed by). What also risks being overlooked is the extent to which practical support and the reallocation of care also benefits others-not just those who would otherwise be burdened with responsibility. Research shows that reasonable adjustments for disabled people, such as fewer in-person workplace meetings, often benefits able-bodied people (Harwood 2016). Treating good care provision as a public obligation not only helps women. It also has the social benefit of bringing more people into care activities, breaching the walls which constitute families as closed sets of obligations and relations.

In this discussion, we have drawn on disability thoughtways to consider gender as relationally and asymmetrically constituted, and as anchored in social relationships and support. In the final part of the article, we build on this account to consider what it would mean to approach gender as a fluctuating condition. What thoughtways does disability equality law here offer?

\section{Fluctuating Intensity, Meaning, and Form}

Disability can vary over time, with more severe effects at some temporal junctures than at others. This is now legally recognised and covered by the definition of disability in the Equality Act. For instance, the official explanatory notes to the Equality Act mention that the current definition of disability includes fluctuating conditions like colitis or multiple sclerosis. ${ }^{38}$ As such, the Equality Act currently makes provision both for those whose disability has a continuous impact on their life, and those for whom disability may be more episodic (Boyd 2012). Equality law considers the overall impact of a specific condition, without the need to show that it always has an effect, or even the same effect, across a person's life. The Equality Act allows for the possibility of someone being disabled in some contexts, but not others, as it sees disability both as plural and non-continuous. This highlights why disability provides such a useful avenue for reflecting on gender in conditions of decertification, as it is one of the most flexible categories under the Equality Act in the sense that a person's status, as well as the meaning or relevance of that status, can vary and change.

We can think of gender as having a similar fluctuating quality. Yet, while claims about gender's fluidity often get made, they tend to collapse different meanings into each other. Fluidity may mean that an individual perceives their gender identity as fluctuating according to context or time. But it can also refer to the social experience of being and feeling gendered in ways that vary in intensity, form, and meaning, with different effects at different moments. This latter understanding emphasises the constitutive and generative role played by social context, something the social model

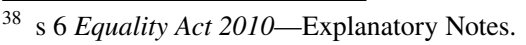


of disability articulates. In this sense, people don't carry their 'own' disability. The interactions between environments and people produce it in different ways (and, in some contexts, may not produce it at all). Likewise, with gender, different environments may produce or fail to produce gender in ways that allow gender's own intensity to fluctuate.

Approaching gender as a fluctuating social condition within equality law is productive for addressing the challenge raised earlier: how to identify or define gender in the absence of a dualist sex-based framework. We discussed earlier different possibilities. Drawing from disability, one option would be to list genders as 'conditions' that people enter and experience in ways which recognise and respond to the institutionalised gender legacies we have inherited, including in relation to pregnancy, menopause, and care responsibilities. This would mean that people could be gendered differently in different contexts. ${ }^{39}$ For instance, in relation to disability, a specific medical issue may only be significant enough to be treated as a disability at specific points, for instance when long periods of standing are required. This might mean that gender is identified as a relevant condition in certain institutional contexts, while being deemed irrelevant or something else entirely in others. Approaching gender as something that fluctuates also attends to the changing conditions that people experience over their life-course. It allows us to identify where gender might be a useful way of identifying or describing a specific experience salient for equality law, without claiming that it is an enduring, always relevant categorisation. This also supports a more intersectional understanding of (in)equality where different issues or characteristics vary in their relevance over time.

Finally, we might consider how the language of chronic illness or chronic conditions can be used to think about gender. The law already recognises that some conditions have 'flare-ups' as well as 'remissions'. ${ }^{40}$ Could we similarly think about gender as something that may flare up at a given time, when it becomes more relevant for equality law, going into remission at other times? Or gender might remain an underlying force with lifelong effects. In the context of maternity or parental leave, for instance, discrimination may only be acutely experienced for a relatively short period of time. However, the effects of such discrimination are often persistent and may re-emerge sharply later on-the effects that decisions around childcare have on women's future pension entitlements, for example. Similarly, some people may, at various times, experience gender more intensely, while some aspects of social life produce a greater gendered impact, for instance around transitional life stages such as puberty or child-rearing. Here disability offers an alternative to the stable status conventionally associated with sex, race, and, to a lesser degree, religion. ${ }^{41}$

To summarise, the legal thoughtways that disability contributes to gender equality law, in conditions of decertification, have three key aspects. First, they attend to

\footnotetext{
39 This may already be happening in some instances, see McConnell \& Anor, $R$ (On the Application Of) $v$ The Registrar General for England and Wales [2020] EWCA Civ 559 (29 April 2020).

40 s 36-39 Equality Act 2010-Explanatory Notes.

41 Committed beliefs are not always presumed to be static and unchanging over a lifetime, e.g. see $R$ (Williamson) v Secretary of State for Education and Employment [2005] UKHL 15, para 23.
} 
the embodied dimensions of gender, but without limiting this to a binary model. Second, they recognise gender's relational character-how gender becomes defined, enacted, and practiced through interaction with other people, things, institutional systems, the built environment, and social norms. Third, a disability-based model does not presume gendered characteristics are stable and constant. At the same time, a disability-based account offers no clear strategies for addressing the contribution that social norms make to inequality; the remedies it offers are largely individual ones. Further, because disability is envisaged as asymmetrical in equality law, a disability-based model is less oriented to a multicultural framework in which differences are seen as able to outlive their relations of inequality and as worthy of respect.

\section{Conclusion}

Contemporary British equality law has emerged from the confluence of social movement activism, liberal legalism, and contemporary forms of knowledge and governmentality. While legal thoughtways face back towards legacies of social and institutionalised inequality, our discussion in this article has faced forward to imagine gender as a new category of equality law in conditions of decertification. Our aim was to explore how this category might work-to demonstrate that de-formalising sex as a legal aspect of personhood would not undermine equality law but offer an opportunity for it to develop in new ways. Religion and disability, two current grounds for equality protections, offer different sets of legal thoughtways for gender's reconstruction.

In British equality law, the protected characteristic of religion foregrounds community traditions, member beliefs, their manifestation, and other practices that ethno-religious communities engage in. This offers legal thoughtways for gender oriented to plurality, where different traditions and modes of experience are treated as equally legitimate - at least formally. Such an approach can reify and pin down difference, but it can also support beliefs and practices that disavow gender and attempt to develop ways of living outside its asymmetrical disciplinary norms. This is an important contribution that a more pluralist legal approach to gender equality can make. At the same time, an equality framework oriented to recognition and support for gender plurality is less adequate at addressing gender as an institutionalised system of inequality - where genders are constituted asymmetrically in relation to each other. A feminist approach to gender, which sees gender as a fundamentally problematic structure, does not see itself mirrored by a legal framework oriented to gender's flourishing and diversity - where gender, like religion, is something to be respected or, at least, not targeted for abolition.

Given the limits that religious legal thoughtways offer for tackling gender as a structure of inequality, our analysis turned to disability as an equality law ground. Attuned to impediments and the difficulties that people with disabilities face, this protected characteristic offers legal thoughtways oriented to support and assistance, and to the undoing of disadvantage in ways that also foreground embodiment and the part material conditions play in determining how bodies experience social life. 
Disability equality law is also helpful in thinking about gender relationally and as a socially embodied relationship that evolves and fluctuates. Equality law assumes (and sometime demands) a degree of constancy when it comes to protection from discrimination on grounds of belief (particularly 'philosophical belief'). A disability-based approach captures gender's changing form as it waxes and wanes across a person's lifespan and across different contexts and environments. However, disability equality law is also limited by its orientation to accommodation and individual adjustment.

In exploring religion and disability, we have not sought to suggest that one framework rather than the other should be applied to gender in conditions of decertification. Rather, we have sought to tease out the array of approaches that these two equality grounds offer. Together, they offer pathways for supporting new genderbased communities and practices, while attending to the disadvantages that both new and existing ways of living and being encounter. Equality law often presents a rather siloed approach to different protected characteristics. This unduly limits the use and versatility of the legal tools developed and available. Our objective in writing this article was to explore some of the choices for gender's development in British equality law. Beyond this, we wanted to contribute to a broader conversation about the legal thoughtways that different equality grounds make available, and the value and implications of their cross-pollination. One question facing equality law reform is whether it should continue to rely on a defined and closed list of protected characteristics or focus, instead, on experiences of inequality, recognising that these may be triggered by uncodified, as well as intersectional, grounds without making these grounds determinative (see also Malleson 2018). While this broader question is outside the focus of our discussion, it poses an issue that our analysis of religious and disability equality law has repeatedly come up against-namely, how do these legal areas understand and constitute their subjects, and what implications does this have for gender?

At the heart of our discussion is the way gender is understood and imagined. Thus, we have foregrounded the tensions between legal thoughtways that emphasise multicultural diversity and the need to support it, and those that emphasise relationality and asymmetrical forms of disadvantage. This tension is familiar. It mirrors the ongoing conflict among feminists over whether gender is best imagined as a structure of domination or as a site of plural self-expression; and whether it can be simultaneously imagined as both (even as what gender means in these two registers may diverge).

The thoughtways we have explored demonstrate how a less polarised understanding can be supported through equality law. But what equality law also makes available, exemplified in the protections that exist for lack of religion or belief, is recognition of ways of living that step outside of established social frameworks. Disability equality defines its scope by excluding those deemed non-disabled from its protections. Religious equality provisions incorporate them-not through an exhaustive list of categories (the 'numerus clausus' Katyal 2017 describes) but by attending to some of the discriminatory and adverse consequences faced by those who refuse or fail to hold specific beliefs or membership. In this article, we have translated this 'absence' into living as agender. From a feminist perspective, recognising people as 
agender should not ignore gender-based socialisation, or the ways in which people may be perceived and treated as gendered. It is also not an argument for disattending to androcentric social and institutionalised norms. But from the perspective of what law makes visible and institutionally possible, legal recognition of agender radically reconfigures our prevailing 'gender-scape'-when it comes to how gender works and how it is understood. Such a move poses interesting speculative questions about how agender might come to be legally filled in as something other (or more) than an absence. Despite its likely focus on individualised forms of refusal, recognising people as agender in equality law has the potential to support a revolutionary change in gender's institutionalised imaginary.

Acknowledgements This article is based on research conducted as part of the ESRC funded project, The Future of Legal Gender, 2018-2022, award number ES/P008968/1. Our analysis has benefited from ongoing discussions about gender and law reform with Emily Grabham, Elizabeth Peel, Robyn Emerton, Han Newman, Jessica Smith — colleagues who have worked with us on the project. We are also deeply grateful to Avi Boukli, Didi Herman, Kate Malleson, and Lucy Vickers for very helpful feedback on earlier drafts; and to the anonymous reviewers of the paper for Feminist Legal Studies.

Open Access This article is licensed under a Creative Commons Attribution 4.0 International License, which permits use, sharing, adaptation, distribution and reproduction in any medium or format, as long as you give appropriate credit to the original author(s) and the source, provide a link to the Creative Commons licence, and indicate if changes were made. The images or other third party material in this article are included in the article's Creative Commons licence, unless indicated otherwise in a credit line to the material. If material is not included in the article's Creative Commons licence and your intended use is not permitted by statutory regulation or exceeds the permitted use, you will need to obtain permission directly from the copyright holder. To view a copy of this licence, visit http://creativecommons.org/licen ses/by/4.0/.

\section{References}

Alidadi, Katayoun. 2012. Reasonable Accommodations for Religion and Belief: Adding Value to Article 9 ECHR and the European Union's Anti-discrimination Approach to Employment? European Law Review 37(6): 693-715.

ASA. 2019. Ban on Harmful Gender Stereotypes in Ads Comes into Force. https:/www.asa.org.uk/news/ ban-on-harmful-gender-stereotypes-in-ads-comes-into-force.html Accessed 17 October 2020.

Barnes, Colin. 2007. Disability Activism and the Struggle for Change: Disability, Policy and Politics in the UK. Education, Citizenship and Social Justice 2: 203-221.

Bi, Suriyah. 2021. Equality Act 10 Years On. Equality Act Review 2021, July. https://www.equalityactrevi ew.co.uk/equality-act-10-years-on-report. Accessed 14 November 2021.

Browne, Kath. 2009. Womyn's Separatist Spaces: Rethinking Spaces of Difference and Exclusion. Transactions of the Institute of British Geographers 34(4): 541-556.

Burns, Judith. 2016. Single-Sex Schools 'Must Adapt for Transgender Pupils'. BBC, 6 April. www.bbc. co.uk/news/education-3594179. Accessed 30 August 2021.

Boyd, Vic. 2012. Are Some Disabilities More Equal than Others? Conceptualising Fluctuating or Recurring Impairments within Contemporary Legislation and Practice. Disability \& Society 27(4): 459-469.

Cannoot, Peter, and Mattias Decoster. 2020. The Abolition of Sex/Gender Registration in the Age of Gender Self-determination: An Interdisciplinary, Queer, Feminist and Human Rights Analysis. International Journal of Gender, Sexuality and Law 1: 26-55.

Carlisle, Steven, and Gregory M. Simon. 2012. Believing Selves: Negotiating Social and Psychological Experiences of Belief. Ethos 40(3): 221-236. 
Carr, Helen. 2014. The Public Sector Equality Duty-A Mainstay of Justice in an Age of Austerity. Journal of Social Welfare and Family Law 36(2): 208-210.

Clarke, Jessica. 2019. They, Them and Theirs. Harvard Law Review 132(3): 18-61.

Connell, Raewyn. 1995. Masculinities. Sydney: Polity Press.

Connell, Raewyn, and James W. Messerschmidt. 2005. Hegemonic Masculinity: Rethinking the Concept. Gender and Society 19: 829-859.

Cooper, Davina. 2014. Everyday Utopias: The Conceptual Life of Promising Spaces. Durham: Duke UP.

Cooper, Davina, and Flora Renz. 2016. If the State Decertified Gender, What Might Happen to its Meaning and Value? Journal of Law \& Society 43(4): 483-505.

Cooper, Davina. 2019a. Feeling Like a State: Desire, Denial, and the Recasting of Authority. Durham: Duke UP.

Cooper, Davina. 2019b. A Very Binary Drama: The Conceptual Struggle for Gender's Future. Feminists@law9(1)

Cooper, Davina. 2020. Towards an Adventurous Institutional Politics: The Prefigurative 'as if' and the Reposing of What's Real. Sociological Review 68(5): 893-916.

Cooper, Davina and Robyn Emerton. 2020. Pulling the Thread of Decertification: What Challenges are Raised by the Proposal to Reform Legal Gender Status? feminists@law 10(2).

Cowan, Sharon, Harry Josephine Giles, Rebecca Hewer, Becky Kaufmann, Meryl Kenny, Sean Morris, and Katie Nicoll Baines. 2020. Sex and Gender Equality Law and Policy: A Response to Murray, Hunter Blackburn and MacKenzie. Scottish Affairs 30(1): 74-95.

Coyle, Emily F., and Lynn S. Liben. 2020. Gendered Packaging of a STEM Toy Influences Children's Play, Mechanical Learning, and Mothers' Play Guidance. Child Development 9(1): 43-62.

Criado-Perez, Caroline. 2019. Invisible Women: Exposing Data Bias in a World Designed for Men. New York: Abrams Books.

Cruz, David B. 2002. Disestablishing Sex and Gender. California Law Review 90(4): 997-1086.

Danchin, Peter, and Louis Blond. 2014. Unlawful Religion: Modem Secular Power and the Legal Reasoning in the JFS Case. Maryland Journal of International Law 29(1): 419-480.

Degener, Theresia. 2016. Disability in a Human Rights Context. Laws 5(3): 35.

Department for Work and Pensions. 2016. How to Sign up to the Disability Confident Employer Scheme. https://www.gov.uk/guidance/disability-confident-how-to-sign-up-to-the-employer-scheme. Accessed 30 August 2021.

Dunne, Peter, and Jule Mulder. 2018. Beyond the Binary: Towards a Third Sex Category in Germany? German Law Journal 19(3): 627-648.

Edge, Peter W. 2012. Determining Religion in English Courts. Oxford Journal of Law and Religion 1(2): 402-423.

Edge, Peter and Lucy Vickers. 2015. Review of Equality and Human Rights Law Relating to Religion or Belief. EHRC. http://hdl.handle.net/20.500.12389/22172 Accessed 4 July 2021.

Flacks, Simon. 2012. Deviant Disabilities: The Exclusion of Drug and Alcohol Addiction from the Equality Act 2010. Social \& Legal Studies 21(3): 395-412.

Fredman, Sandra. 2011. Discrimination Law. Oxford: Oxford University Press.

Fredman, Sandra. 2016. Substantive Equality Revisited. International Journal of Constitutional Law 14(3): 712-738.

Hambler, Andrew. 2020. Beliefs Unworthy of Respect in a Democratic Society: A View from the Employment Tribunal. Ecclesiastical Law Journal 22(2): 234-241.

Harwood, Rupert. 2016. What has Limited the Impact of UK Disability Equality Law on Social Justice? Laws 5(4): 42.

Jivraj, Suhraiya. 2013. The Religion of Law: Race, Citizenship and Children's Belonging. Basingstoke: Palgrave Macmillan.

Jeffreys, Sheila. 2014. Gender Hurts: A Feminist Analysis of the Politics of Transgenderism. London and New York: Routledge.

Jenkins, Katharine. 2016. Amelioration and Inclusion: Gender Identity and the Concept of Woman. Ethics 126(2): 394-421.

Kafer, Alison. 2013. Feminist, Queer, Crip. Bloomington and Indianapolis: Indiana University Press.

Katyal, Sonia K. 2017. The Numerus Clausus of Sex. University of Chicago Law Review 84: 389-495.

Kirsch, Thomas. 2004. Restaging the Will to Believe: Religious Pluralism, Anti-Syncretism, and the Problem of Belief. American Anthropologist 106(4): 699-709.

Lawson, Anna. 2008. Disability and Equality Law in Britain: The Role of Reasonable Adjustment. Oxford and Portland: Hart. 
Lawson, Anna. 2011. Disability and Employment in the Equality Act 2010: Opportunities Seized, Lost and Generated. Industrial Law Journal 40(4): 359-383.

Latour, Bruno, and Michel Serres. 1995. Conversations on Science, Culture and Time. Translated by Roxanne Lapidus. Ann Arbor: University of Michigan Press.

Lloyd, Margaret. 1992. Does She Boil Eggs? Towards a Feminist Model of Disability. Disability, Handicap \& Society 7(3): 207-221.

Malleson, Kate. 2018. Equality Law and the Protected Characteristics. The Modern Law Review 81(4): 598-621.

Manfredi, Simonetta, Lucy Vickers, and Kate Clayton-Hathway. 2018. The Public Sector Equality Duty: Enforcing Equality Rights Through Second-Generation Regulation. Industrial Law Journal 47(3): 365-398.

Martin, Nicola. 2012. Disability Identity-Disability Pride. Perspectives: Policy and Practice in Higher Education 16(1): 14-18.

McColgan, Aileen. 2015. Litigating the Public Sector Equality Duty: The Story So Far. Oxford Journal of Legal Studies 35(3): 453-485.

McRuer, Robert. 2006. Crip Theory: Cultural Signs of Queerness and Disability. New York and London: New York University Press.

Murray, Kath, and Lucy Hunter Blackburn. 2019. Losing Sight of Women's Rights: The Unregulated Introduction of Gender Self-identification as a Case Study of Policy Capture in Scotland. Scottish Affairs 28(3): 262-289.

Montemaggi, Francesca ES.. 2017. Belief, Trust, and Relationality: A Simmelian Approach for the Study of Faith. Religion 47(2): 147-160.

Nedelsky, Jennifer. 1990. Law, Boundaries, and the Bounded Self. Representations 30(Spring): 162-189.

O’Hara, Mary E. 2017. Judge Grants Oregon Resident the Right to be Genderless. NBC News, 23 March. https://www.nbcnews.com/feature/nbc-out/judge-grants-oregon-resident-right-be-gende rless-n736971. Accessed 30 August 2021.

Oliver, Mike. 2013. The Social Model of Disability: Thirty Years On. Disability \& Society 28(7): 1024-1026.

Renz, Flora. 2021. Genders that Don't Matter: Non-binary People and the Gender Recognition Act 2004. In The Queer Outside in UK Law, ed. Senthorun Raj and Peter Dunne, 143-164. Basingstoke: Palgrave Macmillan.

Roseneil, Sasha. 2000. Common Women, Uncommon Practices: The Queer Feminisms of Greenham. London: Cassell.

Ruel, Malcolm. (1982) 2002. Christians as Believers. In A Reader in the Anthropology of Religion, ed. Michael Lambek, 99-113. Reprint. Malden, Mass: Blackwell.

Ryan, Frances. 2019. Crippled: Austerity and the Demonization of Disabled People. Brooklyn: Verso.

Scottish Government. June 2020. Gender Representation on Public Boards (Scotland) Act 2018 - Statutory Guidance. https://www.gov.scot/publications/gender-representation-public-boards-scotl and-act-2018-statutory-guidance/pages/2/. Accessed 30 August 2021.

Segal, Lynne. 2015. Why Feminism?: Gender, Psychology, Politics. New York: Wiley.

Sharpe, Alex. 2020. Will Gender Self-Declaration Undermine Women's Rights and Lead to an Increase in Harms? Modern Law Review 83(3): 539-557.

Stock, Kathleen. 2021. Material Girls: Why Reality Matters for Feminism. London: Fleet.

Stone, Amy L., Elizabeth A. Nimmons, Robert Salcido Jr., and Phillip W. Schnarrs. 2020. Multiplicity, Race, and Resilience: Transgender and Non-binary People Building Community. Sociological Inquiry 90(2): 226-248.

Stychin, Carl F. 2009. Faith in the Future: Sexuality, Religion and the Public Sphere. Oxford Journal of Legal Studies 29(4): 729-755.

Sullivan, Alice. 2020. Sex and the Census: Why Surveys Should Not Conflate Sex and Gender Identity. International Journal of Social Research Methodology 23(5): 517-524.

Venditti, Valeria. 2020. Gender Kaleidoscope: Diffracting Legal Approaches to Reform Gender Binary. International Journal of Gender, Sexuality and Law 1(1): 56-75.

Vickers, Lucy. 2010. Religious Discrimination in the Workplace: An Emerging Hierarchy. Ecclesiastical Law Journal 12(3): 280-303.

Vickers, Lucy. 2011. The Expanded Public Sector Duty: Age, Religion and Sexual Orientation. International Journal of Discrimination and the Law 11(1-2): 43-58.

Vickers, Lucy. 2015. Religion and the Workplace. The Equal Rights Review 14: 106-118. 
Wendell, Susan. 2013. The Rejected Body: Feminist Philosophical Reflections on Disability. London and New York: Routledge.

Williams, Christopher. 2008. The End of the 'Masculine Rule'? Gender-Neutral Legislative Drafting in the United Kingdom and Ireland. Statute Law Review 29: 139-153.

Wippler, Anna J. 2016. Identity Crisis: The Limitations of Expanding Government Recognition of Gender Identity and the Possibility of Genderless Identity Documents. Harvard Journal of Law and Gender 39: 491-554.

Woods, Richard. 2017. Exploring How the Social Model of Disability Can be Re-invigorated for Autism: In Response to Jonathan Levitt. Disability \& Society 32(7): 1090-1095.

Yeadon-Lee, Tracey. 2016. What's the Story? Exploring Online Narratives of Non-binary Gender Identities . International Journal of Interdisciplinary Social and Community Studies 11(2): 19-34.

Publisher's Note Springer Nature remains neutral with regard to jurisdictional claims in published maps and institutional affiliations. 